\title{
A mathematical model by route of transmission and fibrosis progression to estimate undiagnosed individuals with $\mathrm{HCV}$ in different Italian regions
}

Loreta A. Kondili ${ }^{1 *}$, Massimo Andreoni ${ }^{2}$, Alfredo Alberti ${ }^{3}$, Salvatore Lobello ${ }^{4}$, Sergio Babudieri ${ }^{5}$, Antonella De Michina ${ }^{6}$, Rocco Merolla ${ }^{6}$, Walter Marrocco ${ }^{7}$ and Antonio Craxi ${ }^{8}$

\begin{abstract}
Background: Although an increase in hepatitis $\mathrm{C}$ virus (HCV) prevalence from Northern to Southern Italy has been reported, the burden of asymptomatic individuals in different Italian regions is currently unknown.

Methods: A probabilistic approach, including a Markov chain for liver disease progression, was applied to estimate current HCV viraemic burden. The model defined prevalence by geographic area using an estimated annual historical HCV incidence by age, treatment rate, and migration rate from the Italian National database. Viraemic infection by age group was estimated for each region by main HCV transmission routes of individuals for stage F0-F3 (i.e. patients without liver cirrhosis and thus potentially asymptomatic) and F4 (patients with liver cirrhosis, thus potentially symptomatic).

Results: By January 2020, it was estimated that there were 409,184 Italian individuals with HCV (prevalence of 0.68\%; 95\% Cl: 0.54-0.82\%), of which 300,171 (0.50\%; 95\% Cl: 0.4-0.6\%) were stage F0-F3. Considering all individuals with $\mathrm{HCV}$ in stage F0-F3, the geographical distributions (expressed as the proportion of HCV infected individuals by macroarea within the overall estimated number of F0-F3 individuals and prevalence values, expressed as the percentage of individuals with $\mathrm{HCV}$ versus the overall number of individuals for each macroarea) were as follows: North $42.1 \%$ (0.45\%; 95\% Cl: 0.36-0.55\%), Central 24.1\% (0.61\%; 95\% Cl: 0.48-0.74\%), South 23.2\% (0.50\%; 95\% Cl: 0.4-0.61\%), and the Isles $10.6 \%$ (0.49\%; $95 \%$ Cl: $0.39-0.59 \%)$. The population of people who inject drugs accounted for $50.4 \%$ of all individuals infected (F0-F3). Undiagnosed individuals (F0-F3) were $\sim 15$ years younger ( $\sim 50$ years) compared with patients with stage F4 ( 65 years), with similar age distributions across macroareas. In contrast to what has been reported on HCV epidemiology in Italy, an increasing trend in the proportion of potentially undiagnosed individuals with HCV (absolute number within the F0-F3) from South (23.2\%) to North (42.1\%) emerged, independent of similar regional prevalence values.
\end{abstract}

Conclusion: This targeted approach, which addresses the specific profile of undiagnosed individuals, is helpful in planning effective elimination strategies by region in Italy and could be a useful methodology for other countries in implementing their elimination plans.

\footnotetext{
${ }^{*}$ Correspondence: loreta.kondili@iss.it

${ }^{1}$ National Center for Global Health, Istituto Superiore di Sanità, Rome, Italy

Full list of author information is available at the end of the article
} original author(s) and the source, provide a link to the Creative Commons licence, and indicate if changes were made. The images or other third party material in this article are included in the article's Creative Commons licence, unless indicated otherwise in a credit line to the material. If material is not included in the article's Creative Commons licence and your intended use is not permitted by statutory regulation or exceeds the permitted use, you will need to obtain permission directly from the copyright holder. To view a copy of this licence, visit http://creativecommons.org/licenses/by/4.0/. The Creative Commons Public Domain Dedication waiver (http://creativeco mmons.org/publicdomain/zero/1.0/) applies to the data made available in this article, unless otherwise stated in a credit line to the data. 
Keywords: HCV, Undiagnosed, Hepatitis C infection, Prevalence, Markov chain

\section{Background}

Hepatitis $\mathrm{C}$ virus (HCV) is the leading cause of liverrelated morbidity and mortality worldwide. Globally, as many as 71 million individuals are infected with chronic HCV [1, 2], Many HCV infected individuals remain asymptomatic for decades, although progression of the disease accelerates with age $[3,4]$.

Following the availability of direct-acting antiviral drugs (DAAs) for the successful treatment of HCV infection $[5,6]$, focus has been placed on the identification of infected individuals. The identification of this population is necessary to achieve targets for 2030, established by the World Health Organization [7].

Italy is considered the country with the highest HCV prevalence rate in Western Europe [8-10] and we have previously published national estimates on the number of infected individuals using a similar modelling approach [11].

It has previously been estimated that under an assumption of $40 \%$ of infected individuals linked-to-care, viraemic burden would decline by $60 \%$ and eligible patients to treat will be depleted around 2025 leaving a significant proportion of infected individuals undiagnosed and without care [12]. To achieve HCV elimination goals, increased case finding in targeted, high prevalence groups is required.

In Italy, although a national hepatitis plan exists [13], decentralized models of $\mathrm{HCV}$ are still being implemented without any uniform screening strategies exist across regional networks. There is a dedicated fund for free HCV screening approved by law in Italy which needs to be implemented at the Regional level and to this end an estimate of the number of individuals with $\mathrm{HCV}$ for each region is necessary. To address this unmet need, we used a probabilistic approach to estimate the infection rate and a Markov model for liver disease progression. This mathematical modelling approach can be considered a useful tool to aid in the development of national and regional health authority HCV elimination plans.

\section{Methods}

\section{Study design}

A previously validated and published mathematical modelling has been used for the aims of this study [11]. Specifically, the mathematical model employed in the present study may be split into two distinct computations. The first model (previously described elsewhere [11]) computes the number of infected individuals on a national basis from available literature and Italian National database [14], subdivided per age, route of transmission, fibrosis status from 1952 to October 2019. Data from the Italian National Institute of Statistics database ISTAT [14] on internal migration from one region to another were only available from 2002 onwards. Therefore, based on the estimation of the number of infected individuals on a national basis until year 2001, the regional evolution of $\mathrm{HCV}$ transmission and progression (including inter-regional and international migration) starts from the year 2002. The second model, the results of which are presented in this paper, compute the results as previously described [11] until the year 2001 and from the year 2002 also provide the number of infected individuals on a regional basis, subdivided by age, route of transmission, fibrosis status, up to January 2020.

\section{Study population and literature search}

Data on HCV prevalence for routes of infection in high risk groups was obtained from a literature search previously reported in detail [11].

\section{The model}

An evolutionary HCV transmission model was developed and implemented using the open-source programming language Python 3.7. The first stage of the model (termed national phase here forward) has been previously reported [11], beginning in 1952 to the end of 2001 calculating the number of infected individuals by age, route of transmission, and fibrosis status. Briefly, the evolutionary steps consider the insertion of newborns, new infections (the model accounts for six routes of transmission), possible fibrosis evolution (computed using a Markov chain approach), HCV treatment, and liver-related mortality rate. After this stage, the number of individuals with $\mathrm{HCV}$ is subdivided for each region considering the distribution of the population and the variability of risk factors among the different regions is explained in section "Transmission routes and associated risk". Subsequently, the evolution of the HCV transmission and liver disease progression among the Italian population was performed until January 2020, with a method that included the internal (inter-regional) and external (international) migration referred to as regional phase here forward which consists of several steps summarised below with a graphical representation depicted in Fig. 1.

The evolutionary steps performed by the national and regional phases are nearly the same. The regional phase is more accurate and computationally intensive because it includes migration flow. 


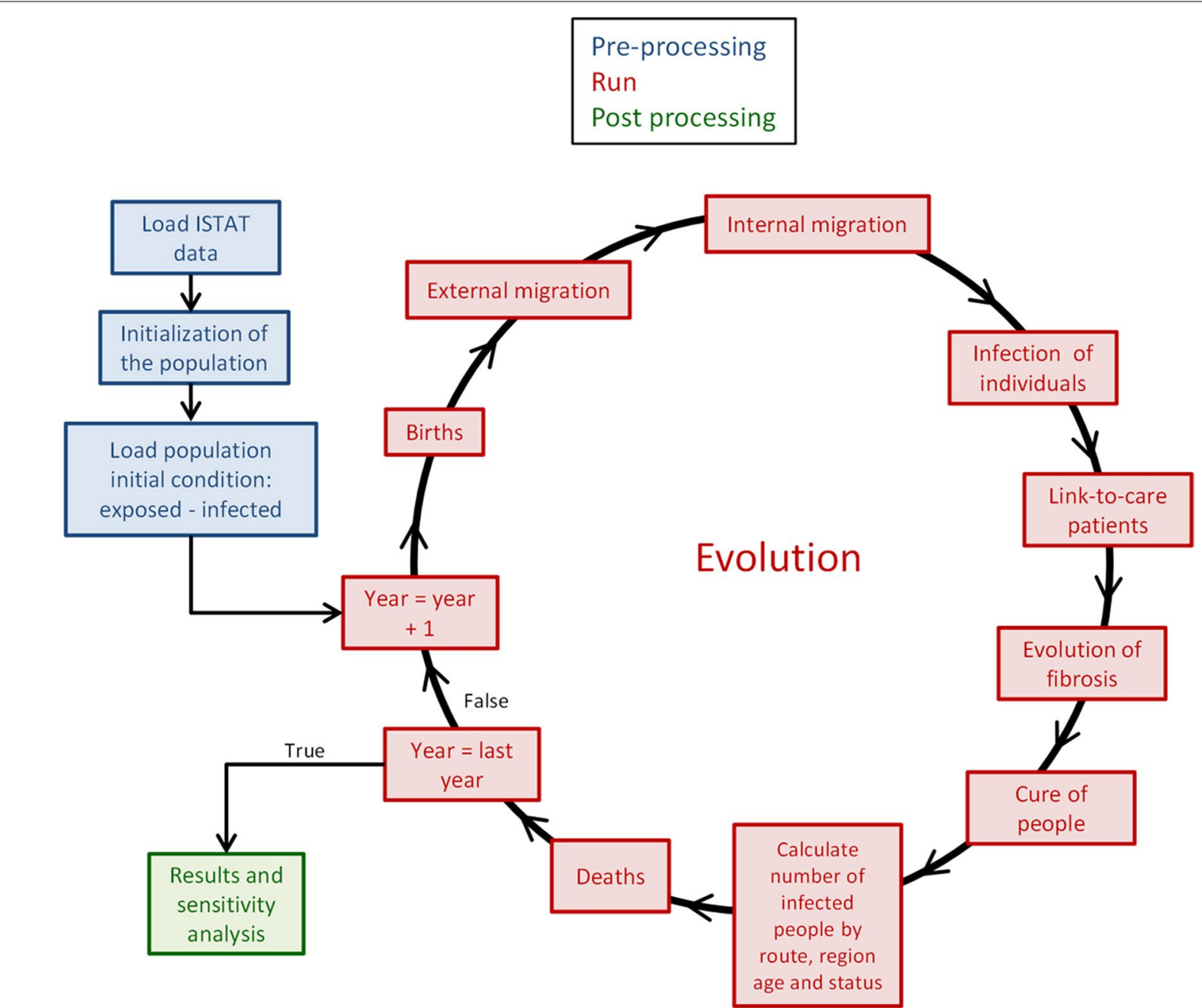

Fig. 1 Schematic presentation of the model evolution loop

An overview of these steps is described below.

1. Newborns: The number of newborns is added, official annual data are provided by ISTAT [14].

2. External migration (only for the regional phase): the movement of people from a foreign country to Italy or vice versa. People who enter Italy are considered healthy; however, they can contract $\mathrm{HCV}$ once they arrive, just as other Italian residents. People who leave Italy are simply removed from the model; they either have or do not have HCV. ISTAT provides a minimum breakdown by age, which is included in our model [14].

3. Internal migration (only for the regional phase): the movement of people from one Italian region to another. People who move between regions can contract HCV. Because ISTAT [14] does not provide information on internal migrants' ages, we pick them independently of their age.

4. Infected individuals: individuals recently contracting $\mathrm{HCV}$ per region, age, and year were considered $[11,15]$. These individuals are added to the previous population of individuals with HCV. The number of new $\mathrm{HCV}$ cases was then calculated following the infection probabilities, depending on the age, transmission route, and current year.

5. Link-to-care patients: the burden of individuals with $\mathrm{HCV}$ treated with interferon (IFN) or DAA provided by Expert Opinion report provided by EpaC (The Italian Liver Patients' Association [EpaC]) and the Italian Medicines Agency (AIFA) Registry for DAA monitoring [16]. 
6. Fibrosis evolution: individuals with $\mathrm{HCV}$ who undergo a possible fibrosis progression according to a Markov chain probability evolution process [11].

7. Mortality: the annual number of deaths per region and age provided by ISTAT [14] was removed. Individuals were randomly (uniform) selected between the populations of those with and those not with $\mathrm{HCV}$. In our model, we accounted for HCV-related mortality by considering the average values of transition probabilities following the F4 fibrosis stage reported by Linthicum et al. [17] and Kondili et al. [18-21]. All transition probabilities were adjusted for competing probabilities of death from other causes according to the official data [ISTAT] [14].

8. Year +1 : individuals are aged 1 year.

Subsequently, the 'loop' restarts, advancing the population for another year. This process repeats until the year 2020 (Fig. 1).

\section{Transmission routes and associated risk}

The model tracked each single route of transmission independently, distributing the weight of the effect of each route over time, as previously described in detail elsewhere [11]. The probability, $P$, of contracting $H C V$ after exposure to a route, in a given year for a person of a given age, can be split as follows:

$$
\begin{aligned}
P(H C V \mid \text { route, age }, \text { year })= & g(\text { HCV |route, age }) \\
& \times f(H C V \mid \text { route }, \text { year }),
\end{aligned}
$$

where both $g$ and $f$ are shape functions that express the dependence of $P$ on the couples: "route - age" and on "route - year of infection". The functions $g$ and $f$ have been described (and plotted) in further detail elsewhere [11].

Data for the following high-risk routes of HCV transmission were considered: people who inject drugs (PWID), tattoos or body piercing, sexual transmission, glass syringe, blood transfusion, and vertical transmission [11]. Key criteria for input of data in the model regarding age and year of infection were defined for each risk group. Based on $\mathrm{HCV}$ prevalence and the time series of Italian population, we reconstructed the probability of infection for ages 0-100, for years from 1952 to 2020, and for the six different infection routes. The formula used follows: where $F$ and $I$ are the fraction of the total Italian population exposed to the route and the viraemic population, respectively. For the regional phase, the number of newly infected individuals is distributed among regions proportionally to the population for each age and each region. The fractions of individuals exposed, the viraemic populations, as well as the functions $f$ and $g$, are obtained from assumptions based on previous studies and described in detail elsewhere [11].

The total burden of infection at the beginning of 2002 was obtained using the results of the national phase [11], divided for each region. The formulas and criteria used to distribute the burden of infection across different regions are described below for each high-risk route of infection.

\section{People who inject drugs}

Regional distribution of PWID is estimated according to the 2002 national report on drug addiction ('Relazione Annuale Al Parlamento Sullo Stato Delle Tossicodipendenze in Italia') [22]. This report documents the number of people per region undergoing treatment for a drug addiction together with HCV. We distributed the number of infected individuals proportionally to the number of individuals under treatment in a SERD ('Servizi per le Tossicodipendenze), both positive and not positive, in the formula:

$$
P W I D(\text { region })=P W I D_{\text {national }} \times \frac{\text { SerT }(\text { region })}{\sum_{\text {all regions }} \operatorname{Ser} T(\text { region })} .
$$

SERD (region) is the number of individuals undergoing treatment in a regional SERD, PWID (region) is the number of PWID individuals per region, and PWID national is the overall number of PWID from the national phase. Therefore, we assume that the number of individuals receiving treatment for substance use disorders at a given centre for a specific region is directly proportional to the total number of PWID in that region. Furthermore, in the computation of the number of infected PWIDs, the number of those treated over time (since the use of IFN then of DAA) were eliminated from the computation.

\section{Tattoo or body piercing}

Regarding the regional phase, data were not available to evaluate the prevalence of this route of infection across different regions. Hence, the number of infected individuals were subdivided proportionally to avoid erroneous

$$
\text { Newlyinfected }(\text { route, year })=\sum_{\text {age }}[g(\text { HCV } \mid \text { route, age }) \times f(\text { HCV } \mid \text { route }, \text { year }) \times F(\text { route }) \times I(\text { route })]
$$


estimates. A region yields the number of those infected for a given age group proportionally to the number of those of that age in the region in the following formula: be around 5.8\% [14, 24]. Reduction of the risk has been modelled with a linear decrease up to $0.015 \%$ [11]. It is also reasonable to assume that the number of infected

$$
N_{\text {infected }}(\text { region, age })=\frac{\text { people }(\text { region, age })}{\sum_{\text {all regions }} \text { people }(\text { region, age })} N_{\text {infected-national }}(\text { age }) .
$$

The relative importance of this route for the new infections is decreasing rapidly (in 2019 it is $\sim 1 / 5$ of the peak value reached in 1995) [11]. However, we cannot refer to this route as "extinct", because it is dependent upon hygiene conditions of individuals performing tattoos and body piercing.

\section{Sexual transmission}

For the regional phase, we adopted the same formula used for the tattoo and body piercing route because, as with that route, data were not available to distribute the prevalence of the sexual transmission route of infection across different regions [11].

\section{Glass syringes}

A higher prevalence was assumed to have occurred at an early age (0-8 years) due to glass syringe vaccination. Ten percent of individuals were assumed to be exposed to glass syringe and $6 \%$ to be infected [11]. Because infection by glass syringe (in 1975 single use of plastic disposable syringes became law in Italy, substituting glass syringes nationwide) or blood transfusion routes did not result in any new HCV cases from 2002, these routes can be referred to as 'extinct' for the regional phase. Considering a recent study by Andriulli et al. [23] where a North-South gradient was observed (higher in the South) with a ratio of South: North of 1.14 and applying this information to our model, a ratio of 1.17 is generated. This value was obtained by ascribing a prevalence value three-fold higher for Southern regions compared with Northern regions.

\section{Blood transfusion}

The distribution profile is the same as that used previously [11]. The year distribution profile starts when the model begins and it peaks in the nineties (when the virus was finally isolated) and it drops smoothly in subsequent years. The regional distribution of the risk has been assumed to be uniform.

\section{Vertical transmission}

The risk of vertical transmission was calculated from the number of mothers with $\mathrm{HCV}$; this female population transfer the virus with a given percentage to newborns (values retrieved from ISTAT]). The risk was estimated to individuals will be proportional to the specific population for each region. Vertical infection occurs at the age of zero, but the infected population undergoes ageing, hence the risk of vertical transmission occupies any age bins.

\section{Patients treated with anti-viral drugs}

Among the estimated number patients treated with antiviral therapy, IFN- and DAA-based treatments were subtracted from the population with $\mathrm{HCV}$, since they are not considered as an 'unknown' population anymore. For some of the years considered, literature and available data sources [11] gives an indication of how this number is distributed among the different fibrosis stage groups; otherwise we used a uniform distribution. From the estimated total number of viraemic patients at risk, we subtracted the number of probable non-viraemic individuals from the model (IFN- and DAA-based treatment) from 1993 to 2019 according to expert report data for IFN treatment until 2015 by EpaC (The Italian Liver Patients' Association [EpaC] [25]) and AIFA Registry data for DAA monitoring [16]. For the period spanning from 2002 to 2014, since we rely on expert opinion, regional treatments have been calculated proportional to the number of infected individuals for each region and they have been uniformly distributed among the 5 fibrosis stages. Starting from 2015, we rely on data from AIFA [16] and regional treatments previously presented (ACE conference 4-November-2019) [26]. Treatments are uniformly distributed between the different routes.

\section{Markov chain progression for fibrosis evolution}

The evolution from one stage to the next is modelled according to a Markov chain approach as has previously been described in detail [11]. Briefly, the following annual transition probabilities have been used in the reference case: $\mathrm{F} 0 \rightarrow \mathrm{F} 1=7.6 \%, \mathrm{~F} 1 \rightarrow \mathrm{F} 2=9.5 \%, \mathrm{~F} 2 \rightarrow \mathrm{F} 3=10.8 \%$, and $\mathrm{F} 3 \rightarrow \mathrm{F} 4=13.4 \%$ [17]. It was assumed that no more than one transition per year could occur per patient. Potential spontaneous liver fibrosis regression was not considered.

\section{Sensitivity analysis}

Sensitivity analysis was performed using a Monte Carlo approach to estimate the effect on the number 
of individuals with $\mathrm{HCV}$ and their annual distribution among the F0-F4 stages, the uncertainty in the fibrosis annual transition probabilities, and the probability of self-curing (recover spontaneously without treatment). Two thousand simulations were run. In each simulation, the self-curing and transition probabilities were derived (independently) from their predefined random distributions.

The distributions of the transition probabilities were logit-normal with mean value equal to the corresponding transition probability used in the reference case [17] and standard deviation equal to $10 \%$ of the mean value. The distribution of the self-curing probability was uniform, with lower bound at $15 \%$ and upper bound at $45 \%$ (thus, the mean value was $30 \%$, as in the reference case [17]). The output of the Monte Carlo consisted of mean values of the different prevalence values computed using our model, together with a $95 \%$ confidence interval (CI), from 2.5 th to 97.5 th percentiles for each one of them.

\section{Results}

$\mathrm{HCV}$ prevalence estimates by Italian region and macroarea The overall number of individuals with HCV by January 2020 in the entire Italian territory, estimated at 409,184 (prevalence of $0.68 \%$; 95\% CI: $0.54-0.82 \%$ ), was distributed across the four macroareas as follows: $0.47 \%$ to $0.67 \%$ in the North, $0.74 \%$ to $1.04 \%$ in the Central, $0.64 \%$ to $1.01 \%$ in the South, and $0.66 \%$ to $0.76 \%$ in the Isles regions. Highest prevalence estimates (percentage of infected individuals versus the overall number of individual inhabitants in a given region) were generally observed in Central Italy, such as Umbria (1.1\%, 95\% CI: 0.88$1.34 \%)$ and Marche (1.04\%, 95\% CI: 0.83-1.26\%), in addition to the Basilicata region in the South $(1.01 \%$, 95\% CI: $0.81-1.22 \%$ ), whereas the majority of Northern regions had a lower estimated prevalence (e.g. Lombardia; $0.47 \%$, 95\% CI: $0.38-0.57 \%$ and Emilia Romagna; 0.51\%, 95\% CI: $0.41-062 \%)$.

The distributions of $\mathrm{HCV}$ prevalence in individuals potentially asymptomatic (stage F0-F3, i.e. patients without liver cirrhosis; estimated to be 300,171) and those with F4 stage disease (and F4 (patients with liver cirrhosis, thus potentially symptomatic; estimated to be 109,012) are shown in Fig. 2A, B, respectively.

The overall $\mathrm{HCV}$ prevalence estimates (percentage of individuals with $\mathrm{HCV}$ versus the overall number of individuals for a given macroarea) of F0-F3 (prevalence of $0.5 \%$, 95\% CI: 0.4-0.6\%) were similar across the four macroareas (Table 1). While prevalence values in the Central and South regions for F4 stage disease (Fig. 2B) were approximately half of F0-F3 individuals (Fig. 2A), prevalence values for F4 individuals in the North region (Fig. 2B) were estimated to be about five-fold less than F0-F3 individuals (Fig. 2A).

\section{Estimation of the proportion of individuals across Italian regions}

Despite similar prevalence values observed across the four macroareas, the 300,171 estimated individuals with F0-F3 fibrosis stage (potentially undiagnosed) were distributed across regions as follows: $42.1 \%$ in the North, followed by $24.1 \%$ in the Central to lower proportions observed in the South (23.2\%), and the Isles (10.6\%) (Table 1). Independent of similar prevalence estimates, the distribution of these individuals revealed the highest absolute numbers in the Lombardia region followed by Lazio, Campania, Veneto, Sicilia, Piemonte, Puglia, Toscana and Emilia Romagna (range: 19,374-41,543) (Table 2). The remaining regions were estimated to have lower numbers, ranging from 658 in Valle d'Aosta to more than 10,000 in Calabria and Marche.

The distribution of individuals with stage F4 disease $(109,012$ estimated individuals) was highest in the Central and Southern regions $(31.8 \%$ and $31.0 \%$, respectively), followed by the Northern (25.7\%) and the Isles (11.5\%) regions (Table 1). Regions reporting the highest estimated numbers of individuals included Lazio $(17,534)$ and Campania $(11,088)$ (Table 2).

\section{Prevalence by high-risk transmission route}

Although marked differences in prevalence estimates across the five high risk groups were observed (Table 3), with the highest seen in the PWID and tattoo groups, little variation in overall prevalence estimates was seen across the four macroareas for each infection route (Table 4). Despite similar prevalence estimates seen by macroarea in undiagnosed individuals (F0-F3 fibrosis stage; range: $0.23-0.31 \%$ ), the estimated absolute number of PWIDs with F0-F3 (total of 151,296 individuals) was approximately two-fold higher in the Northern $(64,922)$ than Central and Southern $(36,674$ and 34,432, respectively) regions, and approximately four-fold higher than the Isles region $(15,268)$ (Table 4). Specific estimated numbers for each region by transmission route are shown in Additional file 1: Table S1.

The estimated number of patients with stage F4 disease in the PWID (total of 47,514 individuals) was highest in the Northern $(15,399)$, followed by the Central $(14,781)$, and the Southern $(12,548)$, regions, and lower in the Isles region (4787) (Table 4).

\section{Prevalence by age range}

Prevalence estimates by age range are shown for stage F0-F3 and F4 disease in Fig. 3A, B, respectively. The highest prevalence estimates for individuals with stage F0-F3 were seen in the 40-49 years' age groups for undiagnosed individuals, decreasing with increasing age, with similar profile maintained for each macroarea (Fig. 3A). 


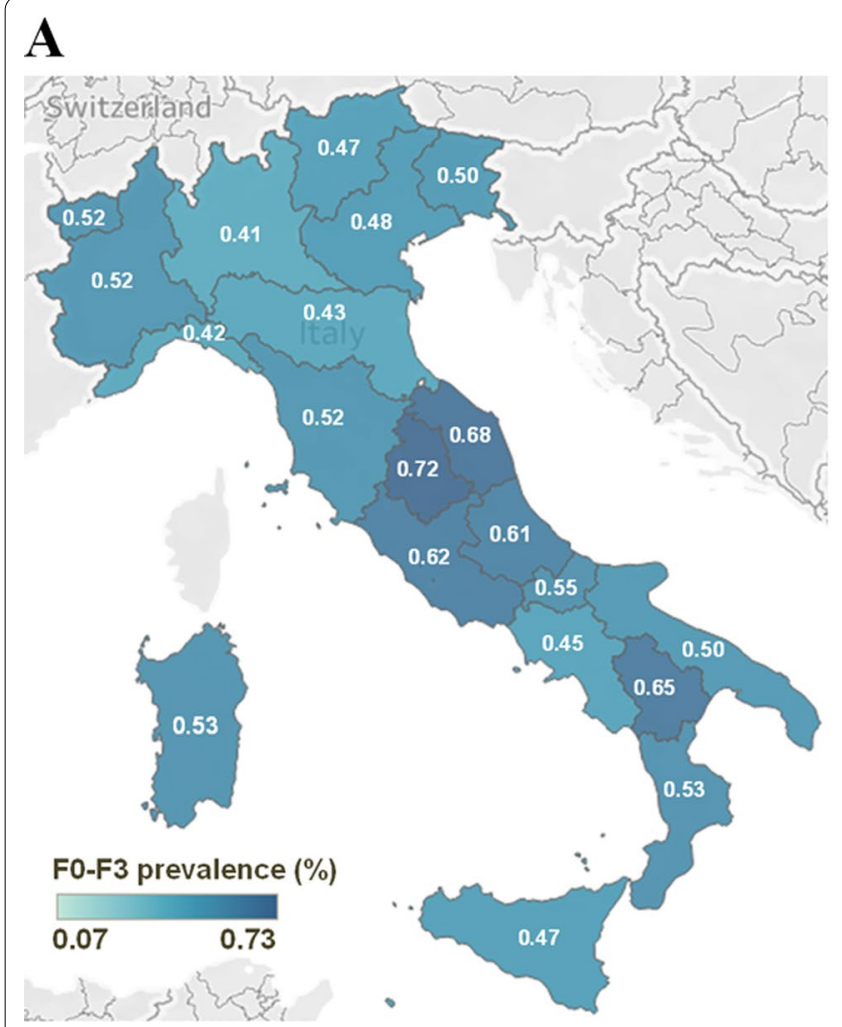

\section{B}

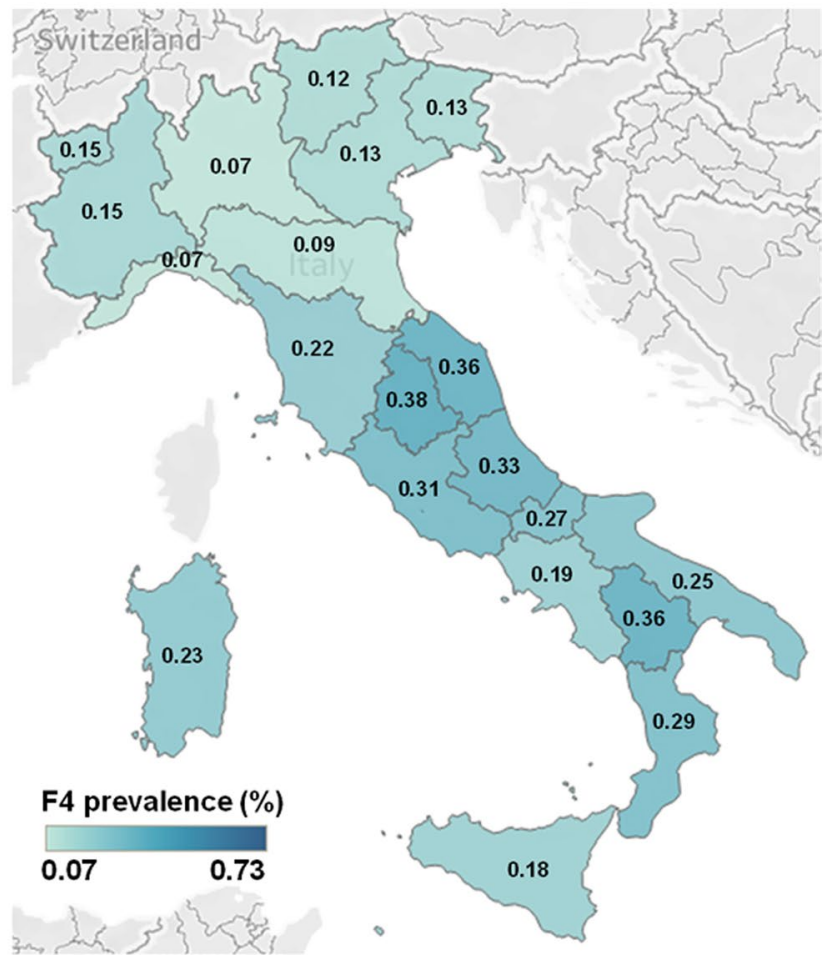

Fig. 2 Maps of the estimated prevalence of HCV in different regions of Italy. A The prevalence of potentially undiagnosed individuals with HCV (stage F0-F3) and B individuals with HCV (stage F4 liver fibrosis; potentially diagnosed) are depicted in the two maps. Prevalence estimates were calculated according to each of the region's population by age group annually since 1952 up to January 1, 2020, from the Italian National database (ISTAT) [14]. F0-F3 = asymptomatic; undiagnosed/unlinked to care; F4= symptomatic; potentially linked to care and cure; HCV = hepatitis C virus. Please note that when referring to prevalence values for a given area (e.g. a region or a macroarea) we refer to the percentage of individuals located in that macro area that are infected

Table 1 Estimates of the absolute number and \% of viraemic HCV individuals in Italy according to fibrosis stage and macro area

\begin{tabular}{|c|c|c|c|}
\hline Macroarea/fibrosis stage & Absolute number and $95 \% \mathrm{Cl}$ & Prevalence (\%) and 95\% Cl (\%) & Proportion (\%) \\
\hline Total & $409,184(325,007-494,591)$ & $0.68(0.54-0.82)$ & \\
\hline Total F0-F3 & $300,171(239,306-365,317)$ & $0.50(0.4-0.6)$ & 100 \\
\hline Total F4 & $109,012(84,886-135,012)$ & $0.18(0.14-0.22)$ & 100 \\
\hline \multicolumn{4}{|l|}{ Macro regions } \\
\hline \multicolumn{4}{|l|}{ North } \\
\hline F0-F3 & $126,376(100,711-153,938)$ & $0.45(0.36-0.55)$ & 42.1 \\
\hline F4 & $27,999(20,654-35,542)$ & $0.10(0.07-0.13)$ & 25.7 \\
\hline \multicolumn{4}{|l|}{ Central } \\
\hline F0-F3 & $72,453(57,742-88,048)$ & $0.61(0.48-0.74)$ & 24.1 \\
\hline $\mathrm{F} 4$ & $34,637(27,160-42,360)$ & $0.29(0.23-0.35)$ & 31.8 \\
\hline \multicolumn{4}{|l|}{ South } \\
\hline F0-F3 & $69,540(55,450-84,629)$ & $0.50(0.4-0.61)$ & 23.2 \\
\hline $\mathrm{F} 4$ & $33,799(26,606-41,515)$ & $0.24(0.19-0.3)$ & 31.0 \\
\hline \multicolumn{4}{|l|}{ Isles } \\
\hline F0-F3 & $31,802(25,304-38,522)$ & $0.49(0.39-0.59)$ & 10.6 \\
\hline F4 & $12,578(9,809-15,614)$ & $0.19(0.15-0.24)$ & 11.5 \\
\hline
\end{tabular}

Fibrosis stages: F0-F3 = asymptomatic; undiagnosed/unlinked to care and F4 = symptomatic; potentially linked to care and cure Cl confidence intervals 
Table 2 Estimates of the absolute number and \% of viraemic HCV individuals in different Italian regions according to fibrosis stage

\begin{tabular}{|c|c|c|c|c|c|c|c|}
\hline \multirow[t]{2}{*}{ Region } & \multirow[t]{2}{*}{ Fibrosis stage } & \multicolumn{3}{|c|}{ Absolute number } & \multicolumn{3}{|c|}{ Prevalence (\%) } \\
\hline & & Number & Lower $95 \% \mathrm{Cl}$ & Upper $95 \% \mathrm{Cl}$ & Mean & Lower $95 \% \mathrm{Cl}$ & Upper $95 \% \mathrm{Cl}$ \\
\hline \multirow[t]{2}{*}{ Abruzzo } & F0-F3 & 7935 & 6327 & 9678 & 0.61 & 0.49 & 0.74 \\
\hline & F4 & 4295 & 3367 & 5223 & 0.33 & 0.26 & 0.4 \\
\hline \multirow[t]{2}{*}{ Basilicata } & F0-F3 & 3668 & 2918 & 4449 & 0.65 & 0.52 & 0.79 \\
\hline & $\mathrm{F} 4$ & 2022 & 1591 & 2466 & 0.36 & 0.28 & 0.44 \\
\hline \multirow[t]{2}{*}{ Calabria } & F0-F3 & 10,506 & 8312 & 12,854 & 0.53 & 0.42 & 0.65 \\
\hline & F4 & 5614 & 4424 & 6826 & 0.29 & 0.22 & 0.35 \\
\hline \multirow[t]{2}{*}{ Campania } & F0-F3 & 25,656 & 20,523 & 31,339 & 0.45 & 0.36 & 0.55 \\
\hline & $\mathrm{F} 4$ & 11,088 & 8493 & 13,784 & 0.19 & 0.15 & 0.24 \\
\hline \multirow[t]{2}{*}{ Emilia-Romagna } & F0-F3 & 19,374 & 15,478 & 23,569 & 0.43 & 0.34 & 0.52 \\
\hline & $\mathrm{F} 4$ & 3879 & 2808 & 5009 & 0.09 & 0.06 & 0.11 \\
\hline \multirow[t]{2}{*}{ Friuli-Venezia Giulia } & F0-F3 & 6149 & 4910 & 7448 & 0.5 & 0.4 & 0.6 \\
\hline & $\mathrm{F} 4$ & 1597 & 1209 & 2009 & 0.13 & 0.1 & 0.16 \\
\hline \multirow[t]{2}{*}{ Lazio } & F0-F3 & 35,804 & 28,516 & 43,440 & 0.62 & 0.5 & 0.76 \\
\hline & $\mathrm{F} 4$ & 17,534 & 13,712 & 21,359 & 0.31 & 0.24 & 0.37 \\
\hline \multirow[t]{2}{*}{ Liguria } & F0-F3 & 6542 & 5198 & 7946 & 0.42 & 0.33 & 0.51 \\
\hline & F4 & 1076 & 794 & 1374 & 0.07 & 0.05 & 0.09 \\
\hline \multirow[t]{2}{*}{ Lombardia } & F0-F3 & 41,543 & 33,179 & 50,408 & 0.41 & 0.33 & 0.49 \\
\hline & F4 & 6894 & 4839 & 9053 & 0.07 & 0.05 & 0.09 \\
\hline \multirow[t]{2}{*}{ Marche } & F0-F3 & 10,618 & 8434 & 12,970 & 0.68 & 0.54 & 0.83 \\
\hline & $\mathrm{F} 4$ & 5557 & 4399 & 6768 & 0.36 & 0.28 & 0.43 \\
\hline \multirow[t]{2}{*}{ Molise } & F0-F3 & 1688 & 1351 & 2051 & 0.55 & 0.44 & 0.66 \\
\hline & $\mathrm{F} 4$ & 851 & 658 & 1036 & 0.27 & 0.21 & 0.33 \\
\hline \multirow[t]{2}{*}{ Piemonte } & F0-F3 & 22,744 & 18,112 & 27,746 & 0.52 & 0.41 & 0.63 \\
\hline & $\mathrm{F} 4$ & 6535 & 4969 & 8175 & 0.15 & 0.11 & 0.19 \\
\hline \multirow[t]{2}{*}{ Puglia } & F0-F3 & 20,088 & 15,988 & 24,403 & 0.5 & 0.4 & 0.61 \\
\hline & $\mathrm{F} 4$ & 9930 & 7779 & 12,245 & 0.25 & 0.2 & 0.31 \\
\hline \multirow[t]{2}{*}{ Sardegna } & F0-F3 & 8614 & 6862 & 10,434 & 0.53 & 0.42 & 0.64 \\
\hline & $\mathrm{F} 4$ & 3693 & 2855 & 4562 & 0.23 & 0.18 & 0.28 \\
\hline \multirow[t]{2}{*}{ Sicilia } & F0-F3 & 23,188 & 18,480 & 28,138 & 0.47 & 0.38 & 0.57 \\
\hline & $\mathrm{F} 4$ & 8884 & 6932 & 11,032 & 0.18 & 0.14 & 0.23 \\
\hline \multirow[t]{2}{*}{ Toscana } & F0-F3 & 19,598 & 15,652 & 23,878 & 0.52 & 0.41 & 0.63 \\
\hline & F4 & 8173 & 6321 & 10,108 & 0.22 & 0.17 & 0.27 \\
\hline \multirow[t]{2}{*}{ Trentino Alto Adige/Südtirol } & F0-F3 & 5123 & 4108 & 6205 & 0.47 & 0.38 & 0.57 \\
\hline & $\mathrm{F} 4$ & 1352 & 1038 & 1679 & 0.12 & 0.1 & 0.15 \\
\hline \multirow[t]{2}{*}{ Umbria } & F0-F3 & 6433 & 5161 & 7814 & 0.72 & 0.58 & 0.88 \\
\hline & $\mathrm{F} 4$ & 3374 & 2654 & 4109 & 0.38 & 0.3 & 0.46 \\
\hline \multirow[t]{2}{*}{ Valle d'Aosta/Vallée d'Aoste } & F0-F3 & 658 & 531 & 797 & 0.52 & 0.42 & 0.64 \\
\hline & $\mathrm{F} 4$ & 183 & 137 & 229 & 0.15 & 0.11 & 0.18 \\
\hline \multirow[t]{2}{*}{ Veneto } & F0-F3 & 24,243 & 19,288 & 29,506 & 0.48 & 0.39 & 0.59 \\
\hline & F4 & 6483 & 4860 & 8171 & 0.13 & 0.1 & 0.16 \\
\hline
\end{tabular}

Fibrosis stages: F0-F3 = asymptomatic; undiagnosed/unlinked to care and F4 = symptomatic; potentially linked to care and cure

$\mathrm{Cl}$ confidence intervals

In contrast, for individuals with F4 stage disease, the highest prevalence was focused in individuals 60 years and older (Fig. 3B).

\section{Sensitivity analysis}

The sensitivity of our model by route of transmission for the different macroareas for F0-F3 and F4 individuals are 
Table 3 Estimates of the absolute number and \% of viraemic HCV individuals in Italy according to fibrosis stage and route of transmission

\begin{tabular}{|c|c|c|c|}
\hline Macroarea/fibrosis stage & Absolute number and $95 \% \mathrm{Cl}$ & Prevalence (\%) and $95 \% \mathrm{Cl}(\%)$ & Proportion (\%) \\
\hline Total & $409,184(325,007-494,591)$ & $0.68(0.54-0.82)$ & \\
\hline Total F0-F3 & $300,171(239,306-365,317)$ & $0.50(0.4-0.6)$ & 100 \\
\hline Total F4 & $109,012(84,886-135,012)$ & $0.18(0.14-0.22)$ & 100 \\
\hline \multicolumn{4}{|l|}{ Transmission route } \\
\hline \multicolumn{4}{|l|}{ GS + transfusion } \\
\hline F0-F3 & $15,412(12,155-18,986)$ & $0.02(0.02-0.03)$ & 5.1 \\
\hline F4 & $44,595(35,032-54,287)$ & $0.07(0.06-0.09)$ & 40.9 \\
\hline \multicolumn{4}{|l|}{ PWID } \\
\hline F0-F3 & $151,296(120,700-184,164)$ & $0.25(0.2-0.3)$ & 50.4 \\
\hline $\mathrm{F} 4$ & $47,514(36,507-59,336)$ & $0.08(0.06-0.1)$ & 43.6 \\
\hline \multicolumn{4}{|l|}{ Sex } \\
\hline F0-F3 & $42,591(33,928-51,625)$ & $0.07(0.06-0.09)$ & 14.2 \\
\hline F4 & $3,249(2393-4093)$ & $0.01(0-0.01)$ & 3.0 \\
\hline \multicolumn{4}{|l|}{ Tattoo } \\
\hline F0-F3 & $89,236(71,153-108,577)$ & $0.15(0.12-0.18)$ & 29.7 \\
\hline F4 & $12,414(9177-15,912)$ & $0.02(0.02-0.03)$ & 11.4 \\
\hline \multicolumn{4}{|l|}{ Vertical } \\
\hline F0-F3 & $1,637(1306-2008)$ & $<0.01(<0.01-<0.01)$ & 0.55 \\
\hline F4 & $1,241(958-1523)$ & $<0.01(<0.01-<0.01)$ & 1.14 \\
\hline
\end{tabular}

Fibrosis stages: F0-F3 = asymptomatic; undiagnosed/unlinked to care and F4 = symptomatic; potentially linked to care and cure

$\mathrm{Cl}$ confidence intervals, GS glass syringe, $H C V$ hepatitis $C$ virus, PWID people who inject drugs

shown in Figs. 4 and 5, respectively. In individuals with F0-F3 disease (Fig. 4), variation around the mean (upper and lower 95\% CIs) was narrow for the lower age categories (20-40 years) and widens for the peak prevalence, to a greater extent in the PWID group and sexual transmission compared with other groups. This trend remained similar across the four macroareas (Fig. 4A-D).

In individuals with F4 disease (Fig. 5), the pattern of infection across the four macroareas was different. The overall prevalence estimates were lower, particularly in the North (Fig. 5A), compared with the other macroareas (Fig. 5B-D). For F4 prevalence, the variation around the reference case is approximately proportional to the value of the reference case itself. Overall variation around mean values was $10 \%-15 \%$, indicating robustness of the model.

\section{Discussion}

Findings from the present study revealed that an increasing trend in the undiagnosed population with HCV (FOF3) from South (23.2\%) to North (42.1\%), independent of similar regional prevalence values. PWID and tattoo risk emerged as the main populations of undiagnosed individuals, with similar distribution observed across regions.

The estimated number (and distribution across Italy) of patients with F4 cirrhosis is particularly concerning.
This was unexpected, considering their potential symptomatic disease and the high importance of viral eradication in these patients, who were prioritized for treatment since 2015, when DAAs became available. In fact, around $20 \%$ of patients with cirrhosis are also observed in the AIFA treatment DAA monitoring registry for the year 2019 [16]. These data could suggest the lack of an adequate linkage to care in diagnosed individuals or the first diagnosis of these patients in very severe stages of liver disease, which again emphasises the increased need for screening and immediate linkage to care of individuals with $\mathrm{HCV}$ in Italy.

Although a higher estimated $\mathrm{HCV}$ prevalence of undiagnosed individuals emerged from some specific regions in Central Italy (e.g. Umbria and Marche) and in the Basilicata region in the South, similar lower prevalence estimates of undiagnosed individuals were generally observed across the four macroareas. This suggests a decrease in the level of prevalence in HCV infection compared to the past in Italy where higher prevalence values and a gradient from North to South (3.9\% in Veneto to $16.2 \%$ in Campania) of individuals with $\mathrm{HCV}$ in Italy mainly related to the nosocomial transmission of infection $[8,27]$. However, considering the distribution of the number of undiagnosed individuals $(\mathrm{N}=300,171)$, an increasing trend as absolute 
Table 4 Estimates of the absolute number and \% of viraemic HCV individuals in Italy according to fibrosis stage, route of transmission and macro area

\begin{tabular}{|c|c|c|c|c|c|c|c|c|}
\hline \multirow[t]{2}{*}{ Macroarea } & \multirow[t]{2}{*}{ Transmission route } & \multirow[t]{2}{*}{ Fibrosis stage } & \multicolumn{3}{|c|}{ Absolute number } & \multicolumn{3}{|c|}{ Prevalence (\%) } \\
\hline & & & Number & Lower $95 \% \mathrm{Cl}$ & Upper $95 \% \mathrm{Cl}$ & Mean & Lower $95 \% \mathrm{Cl}$ & Upper $95 \% \mathrm{Cl}$ \\
\hline \multirow[t]{10}{*}{ North } & GS + transfusion & F0-F3 & 3318 & 2591 & 4118 & 0.01 & 0.01 & 0.01 \\
\hline & & F4 & 6817 & 5211 & 8384 & 0.02 & 0.02 & 0.03 \\
\hline & PWID & F0-F3 & 64,922 & 51,853 & 79,217 & 0.23 & 0.18 & 0.28 \\
\hline & & F4 & 15,399 & 11,393 & 19,517 & 0.05 & 0.04 & 0.07 \\
\hline & Sex & F0-F3 & 18,722 & 14,870 & 22,705 & 0.07 & 0.05 & 0.08 \\
\hline & & F4 & 1156 & 816 & 1482 & $<0.01$ & $<0.01$ & 0.01 \\
\hline & Tattoo & F0-F3 & 38,761 & 30,970 & 47,218 & 0.14 & 0.11 & 0.17 \\
\hline & & $\mathrm{F} 4$ & 4260 & 3026 & 5614 & 0.02 & 0.01 & 0.02 \\
\hline & Vertical & F0-F3 & 652 & 508 & 827 & $<0.01$ & $<0.01$ & $<0.01$ \\
\hline & & $\mathrm{F} 4$ & 367 & 271 & 474 & $<0.01$ & $<0.01$ & $<0.01$ \\
\hline \multirow[t]{10}{*}{ Central } & GS + transfusion & F0-F3 & 4713 & 3681 & 5780 & 0.04 & 0.03 & 0.05 \\
\hline & & $\mathrm{F} 4$ & 14,882 & 11,763 & 18,069 & 0.12 & 0.1 & 0.15 \\
\hline & PWID & F0-F3 & 36,674 & 29,263 & 44,609 & 0.31 & 0.24 & 0.37 \\
\hline & & F4 & 14,781 & 11,568 & 18,194 & 0.12 & 0.1 & 0.15 \\
\hline & Sex & F0-F3 & 9796 & 7819 & 11,863 & 0.08 & 0.07 & 0.1 \\
\hline & & F4 & 922 & 690 & 1156 & 0.01 & 0.01 & 0.01 \\
\hline & Tattoo & F0-F3 & 20,894 & 16,638 & 25,354 & 0.17 & 0.14 & 0.21 \\
\hline & & F4 & 3687 & 2793 & 4645 & 0.03 & 0.02 & 0.04 \\
\hline & Vertical & F0-F3 & 376 & 297 & 462 & $<0.01$ & $<0.01$ & $<0.01$ \\
\hline & & F4 & 365 & 291 & 449 & $<0.01$ & $<0.01$ & $<0.01$ \\
\hline \multirow[t]{10}{*}{ South } & GS + transfusion & F0-F3 & 5423 & 4242 & 6733 & 0.04 & 0.03 & 0.05 \\
\hline & & F4 & 17,035 & 13,367 & 20,767 & 0.12 & 0.1 & 0.15 \\
\hline & PWID & F0-F3 & 34,432 & 27,465 & 41,917 & 0.25 & 0.2 & 0.3 \\
\hline & & $\mathrm{F} 4$ & 12,548 & 9707 & 15,594 & 0.09 & 0.07 & 0.11 \\
\hline & Sex & F0-F3 & 9444 & 7523 & 11,516 & 0.07 & 0.05 & 0.08 \\
\hline & & F4 & 799 & 589 & 1003 & 0.01 & $<0.01$ & 0.01 \\
\hline & Tattoo & F0-F3 & 19,834 & 15,787 & 24,109 & 0.14 & 0.11 & 0.17 \\
\hline & & $\mathrm{F} 4$ & 3064 & 2281 & 3925 & 0.02 & 0.02 & 0.03 \\
\hline & Vertical & F0-F3 & 407 & 316 & 512 & $<0.01$ & $<0.01$ & $<0.01$ \\
\hline & & F4 & 354 & 281 & 439 & $<0.01$ & $<0.01$ & $<0.01$ \\
\hline \multirow[t]{10}{*}{ Isles } & GS + transfusion & F0-F3 & 1958 & 1525 & 2404 & 0.03 & 0.02 & 0.04 \\
\hline & & $\mathrm{F} 4$ & 5861 & 4626 & 7192 & 0.09 & 0.07 & 0.11 \\
\hline & PWID & F0-F3 & 15,268 & 12,147 & 18,505 & 0.23 & 0.19 & 0.28 \\
\hline & & F4 & 4787 & 3722 & 5964 & 0.07 & 0.06 & 0.09 \\
\hline & Sex & F0-F3 & 4628 & 3681 & 5632 & 0.07 & 0.06 & 0.09 \\
\hline & & F4 & 372 & 274 & 484 & 0.01 & $<0.01$ & 0.01 \\
\hline & Tattoo & F0-F3 & 9748 & 7782 & 11,851 & 0.15 & 0.12 & 0.18 \\
\hline & & F4 & 1403 & 1037 & 1843 & 0.02 & 0.02 & 0.03 \\
\hline & Vertical & F0-F3 & 201 & 155 & 253 & $<0.01$ & $<0.01$ & $<0.01$ \\
\hline & & $\mathrm{F} 4$ & 155 & 111 & 202 & $<0.01$ & $<0.01$ & $<0.01$ \\
\hline
\end{tabular}

Fibrosis stages: $\mathrm{F} 0-\mathrm{F} 3$ = asymptomatic; undiagnosed/unlinked to care and F4 = symptomatic; potentially linked to care and cure Cl confidence intervals, GS glass syringe, $H C V$ hepatitis $C$ virus, $P W I D$ people who inject drugs

number from the South (23.2\%) to North (42.1\%) emerged. Why our data suggest a different gradient as absolute estimates of undiagnosed individuals, which is higher in the Northern region compared with other macroareas, may be explained by some epidemiologic and sociodemographic features. First, considering the cohort effect of $\mathrm{HCV}$ infection in Italy, infections that occurred in the first wave of infection have a higher 


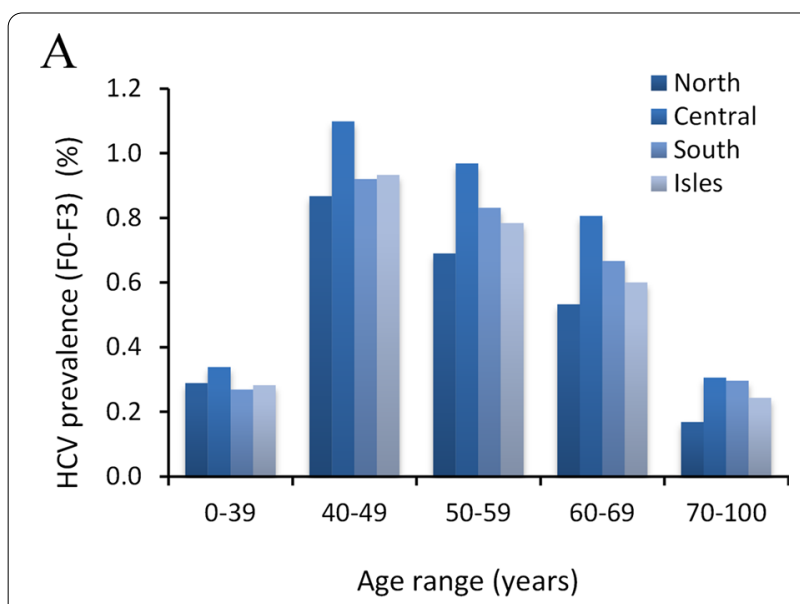

B

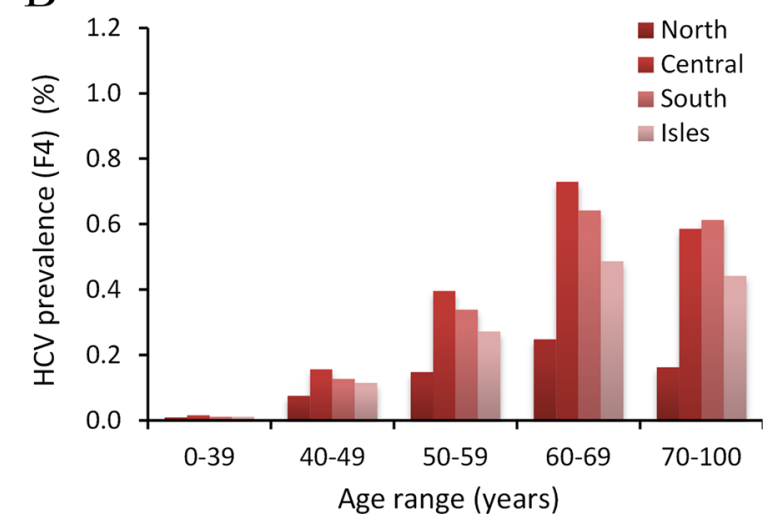

Fig. 3 Estimated prevalence of HCV in different macroareas of Italy by age groups. A The prevalence of potentially undiagnosed infected individuals (stage F0-F3) and (B) infected individuals with stage F4 liver fibrosis (potentially diagnosed). Prevalence estimates are presented as percentage for the four macroareas. F0-F3 = asymptomatic; undiagnosed/unlinked to care;

$\mathrm{F} 4=$ symptomatic; potentially linked to care and cure; $\mathrm{HCV}=$ hepatitis C virus

probability of being cured by now. Therefore, the high number of patients with fibrosis stage F4/cirrhosis receiving treatment in Italy at the beginning have contributed potentially to the substantial decrease in the number of infected individuals who have had severe liver damage (mainly prevalent in the South). The second wave was mainly associated with key populations (i.e. PWID and tattoos), and the more recent infection that has also been reported in Northern Europe [28, 29].

Second, the number of F0-F3 infections could be higher in the North compared with other macroareas due to the internal migration of the Italian population who are actively working (aged 30-60 years) from the
South and Islands to the Northern areas, where there is a higher rate of employment and work activity in the country [30]. Of note, these data do not emerge when only the overall prevalence estimated for each macroarea is considered. This can be explained by the fact that the prevalence values consider the whole population with the same age and population, which is also higher in number (the denominator) in Northern compared with Southern Italy. This yields a similar estimated prevalence, despite high absolute infection burden of asymptomatic individuals in the North compared with other macroareas.

While these findings underline the high HCV burden of asymptomatic individuals in the North, substantial heterogeneity exists across regions, necessitating individual elimination plans to be implemented at the regional level.

The recommended screening approved by law starting with birth in the years 1969-1989 is in accordance with the results of this study, although derived using different modelling approaches [31,32].

It is also worth mentioning that our analysis in the present study was performed up to January 2020, a few months before the severe acute respiratory syndrome coronavirus 2 (SARS-CoV-2) virus pandemic [33]. To cope with the increase in number of COVID-19 patients to emergency departments, the re-organization of healthcare facilities across all Italian regions was necessary resulting in the postponing of medical services and procedures considered as 'non-essential' or 'deferrable'. The potential impact of this deferral has been assessed in a separate analysis by Kondili et al. [34]. In this modelling approach, it was estimated that deferring DAA treatment for an additional 6 months would, at 5 years, increase the number of HCV patients dying of a liver-related condition in Italy to more than 500 patients, deaths avoidable by a not deferred test and treatment approach. A further analysis also revealed that a 1-year delay in hepatitis diagnosis and treatment could result in an additional 44,800 liver cancers and 72,300 deaths from HCV globally by 2030 [35]. Regions such as Lombardy may be particularly susceptible to any deferral of DAA treatment [36], and strategies aimed to increase diagnosis and treatment are warranted.

\section{Limitations}

This study has some potential limitations that need to be highlighted. The impact of less frequent routes of transmission (e.g. surgical interventions, colonoscopy, dental intervention/surgery, cosmetics) was not considered, potentially underestimating the number of both diagnosed and undiagnosed individuals. 


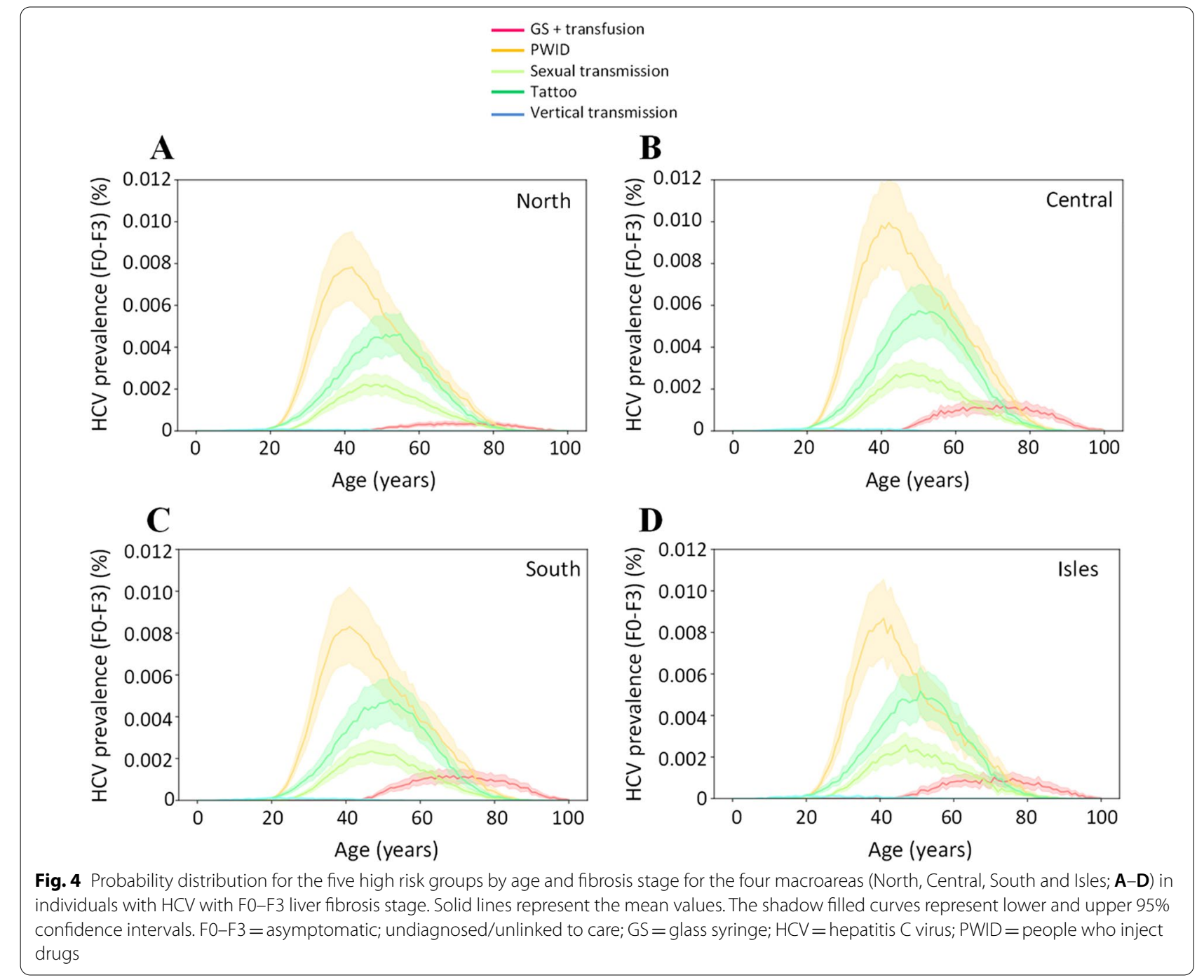

We acknowledge that variation in prevalence rates was estimated considering baseline rates derived from studies that were not always designed as prevalence studies in the general population and for populations with different risk factors such as sexual transmission, which for this reason could have been underestimated. To partially overcome these limitations, the prevalence retrieved from these articles was not used as a uniform probability throughout all years and ages, but a shape (probability density function modelling) was derived from different sources to more realistically model the prevalence over different years. However, considering the high rate of treatment in Italy in the past 5 years and considering DAA treatment as a preventative measure, the rate of reinfection and new infection would be expected to be low, therefore reducing the extent of any potential underestimation.

We considered non-liver related mortality (i.e. natural mortality due to other comorbid diseases) based on
ISTAT (Italian mortality registry) data that are usually used in modelling analysis of HCV natural history. This could have overestimated the alive population with $\mathrm{HCV}$ infection estimated. The non-liver related mortality population could be higher than those infected compared to the general population due to extrahepatic manifestations of $\mathrm{HCV}$ infection, placing them at higher risk of death earlier in life [37]. However, this probability has not been modelled due to the lack of numerical data.

A high number of unregistered immigrants (potentially asymptomatic and undiagnosed for $\mathrm{HCV}$ ) travelling to Italy in recent years $[38,39]$, and particularly in the Northern regions [40] where the highest number of individuals with $\mathrm{HCV}$ was observed in our model. This aspect needs to be carefully considered during the interpretation of our estimates. However, based on expert opinion and data derived from other studies, a higher HCV prevalence is not observed in this 


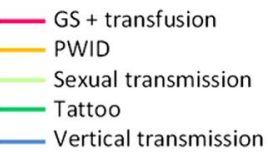

A

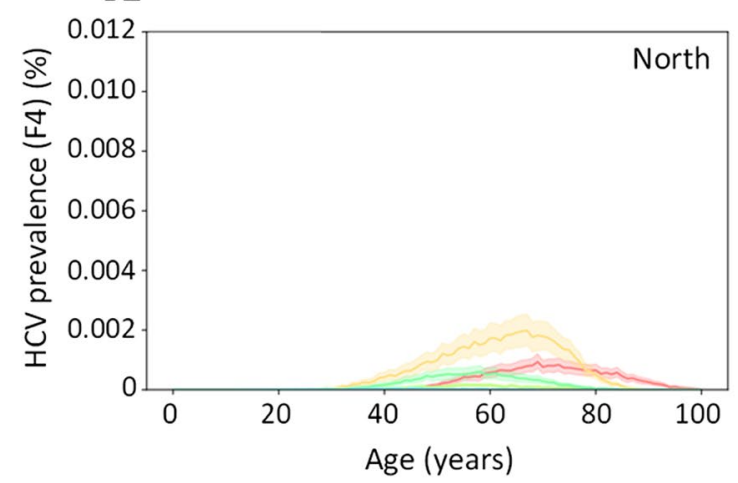

C

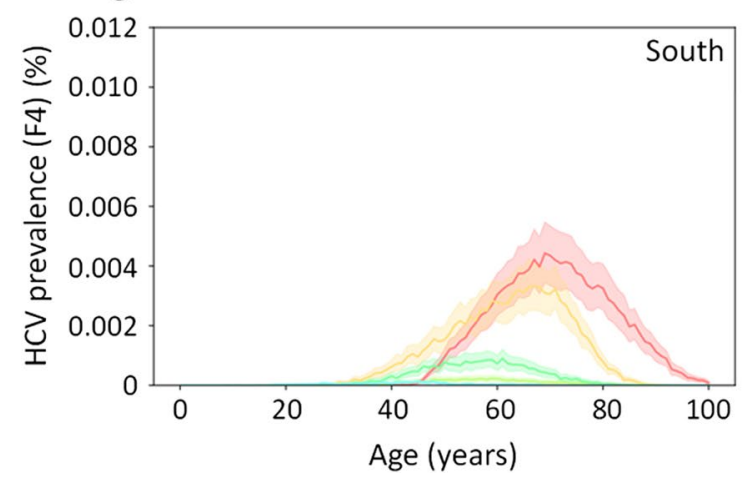

B

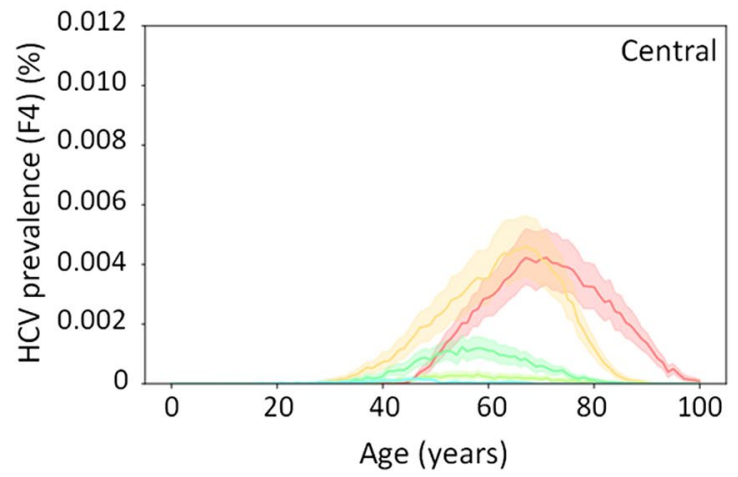

D

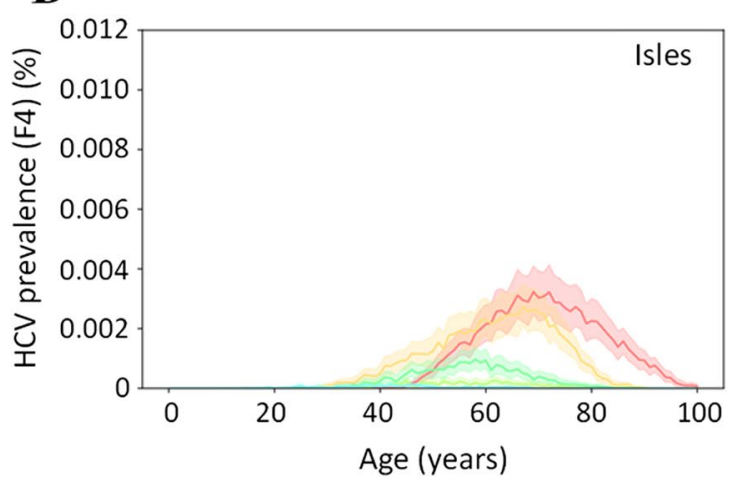

Fig. 5 Probability distribution for the five high risk groups by age and fibrosis stage for the four macroareas (North, Central, South and Isles; A-D) in individuals with HCV with F4 liver fibrosis stage. Solid lines represent the mean values. The shadow filled curves represent lower and upper 95\% confidence intervals. F4= symptomatic; potentially linked to care and cure; GS= glass syringe; HCV=hepatitis C virus; PWID = people who inject drugs

immigrant population (considering their countries of birth) compared to the Italian population (resident in Italy that are included in general population estimates) [41]. In separate analyses, we are working to address not only the higher prevalence rate, but also the impact that this brings to society. In this study, the main routes of infections have been considered separately in the evaluation of the number of untreated individuals in Italy and we have not focussed on specific settings (e.g. immigrant or prison population) mainly due to the lack of reliable National data. Further studies should explore the impact of the immigrant population on HCV prevalence separately.

With regard to the prison population, most prisoners have a history of high-risk sexual behavior, injection drug use and tattooing and it appears that the risk of acquisition of HCV infection is linked to these behaviours which are considered in this modelling. For the aim of this study, in the evaluation of the number of untreated individuals in Italy, the main routes of infection were considered separately by risk factor and not specific settings such as homeless, migrants etc., mainly due to the lack of reliable National data. The prison per se was not considered a route of infection, but PWID is recognised as a main route of infection in prison [4244] rather than the prisoning state itself, and this could result in potential underestimation bias and this could result in potential underestimation bias.

Transition probabilities may vary for different populations that depend on host response and underlying comorbidities [37]. We have aimed to minimize this variation by considering this uncertainty in the sensitivity analysis.

In this model, we assumed that all F0-F3 infected individuals estimated in the model that were not yet treated as undiagnosed. In the real-life scenario, not all 
F0-F3 are undiagnosed and therefore a portion of these individuals could be diagnosed and not yet linked to care. Regardless, these data do not influence the infection burden, because although these individuals could be diagnosed, they are estimated as not treated.

\section{Conclusion}

By January 2020, the number of individuals with HCV in Italy was estimated at 409,184 (prevalence of $0.68 \%$; 95\% CI: $0.54-0.82 \%)$, of which 300,171 (0.50\%; 95\% CI: $0.4-0.6 \%)$ were estimated as undiagnosed due to their asymptomatic disease (F0-F3). The target for new diagnosis should focus and screening of PWID, tattoo, and sexual transmission, in younger people (predominantly aged 40-60 years) should be implemented.

An increasing trend in the percentage of the undiagnosed population with $\mathrm{HCV}$ (F0-F3) from South (23.2\%) to North $(42.1 \%)$ has emerged, independent of similar regional prevalence values. PWID and those who received tattoos in the past represent the main populations of undiagnosed individuals, with similar distributions across regions. This targeted modelling approach, which addresses the specific profile of undiagnosed individuals, is helpful in planning effective elimination strategies by region in Italy and could be a useful methodology for other countries in implementing their elimination plans.

\section{Supplementary Information}

The online version contains supplementary material available at https://doi, org/10.1186/s12879-022-07042-w.

Additional file 1: Table S1. Estimates of \% of viraemic HCV individuals in different Italian regions according to fibrosis stage and high-risk groups.

\section{Acknowledgements}

The authors wish to thank Francesca Petrarca, PhD (IWS Consulting, Rome, Italy), for performing statistical modelling and Colin Gerard Egan, PhD (CE Medical Writing SRLS, Pisa, Italy), for his support in medical writing, both funded by AbbVie.

\section{Authors' contributions}

$L A K, A D$, and $R M$ participated in the study design and supervised the analysis and development of the project. All authors participated in discussions regarding the input of data used in modelling and interpretation of data and results obtained. LAK developed the manuscript, and all authors read and approved the final manuscript version.

\section{Funding}

The design, study conduct, and financial support for the study were provided by AbbVie. AbbVie participated in the interpretation of data, review, and approval of the publication.

\section{Availability of data and materials}

All datasets presented in this study are included in the article/Additional file. Additional data can be made available upon request from $A D$ and RM.

\section{Declarations}

Ethics approval and consent to participate

Not applicable.

\section{Consent for publication}

Not applicable.

\section{Competing interests}

LAK received teaching grants from AbbVie and Gilead. MA received advisor/ speaker/research Grant from AbbVie, Gilead, MSD, ViiV, Janssen-Cilag, and BMS. AA received advisor/research Grants from AbbVie, Gilead, and MSD. SB received advisor/research Grants from AbbVie, Gilead, and Otsuka. AC, SL, and WM have nothing to disclose. RM and ADM are AbbVie employees and may own AbbVie stocks and options.

\section{Author details}

${ }^{1}$ National Center for Global Health, Istituto Superiore di Sanità, Rome, Italy. ${ }^{2}$ University of Tor Vergata, Rome, Italy. ${ }^{3}$ Department of Molecular Medicine DMM, University of Padova, Padua, Italy. ${ }^{4}$ Health Unit Euganea, Padua, Italy.

${ }^{5}$ University of Sassari, Sassari, Italy. ${ }^{6}$ Medical Department AbbVie Italy, Rome, Italy. ${ }^{7}$ F.I.M.M.G., Rome, Italy. ${ }^{8}$ Gastroenterology and Liver Unit, DiBiMIS, University of Palermo, Palermo, Italy.

Received: 7 May 2021 Accepted: 17 November 2021

Published online: 17 January 2022

\section{References}

1. Polaris Observatory HCV Collaborators. Global prevalence and genotype distribution of hepatitis C virus infection in 2015: a modelling study. Lancet Gastroenterol Hepatol. 2017;2:161-76.

2. World Health Organization. World Health Organization, Global Hepatitis Programme. Global hepatitis report, 2017. 2017. http://apps.who.int/iris/ bitstream/10665/255016/1/9789241565455-eng.pdf?ua=1. Accessed 29 May 2019.

3. Hajarizadeh B, Grebely J, Dore GJ. Epidemiology and natural history of HCV infection. Nat Rev Gastroenterol Hepatol. 2013;10:553-62.

4. Sweeting MJ, De Angelis D, Neal KR, Ramsay ME, Irving WL, Wright M, et al. Estimated progression rates in three United Kingdom hepatitis $C$ cohorts differed according to method of recruitment. J Clin Epidemiol. 2006:59:144-52.

5. Afdhal N, Zeuzem S, Kwo P, Chojkier M, Gitlin N, Puoti M, et al. Ledipasvir and sofosbuvir for untreated HCV genotype 1 infection. N Engl I Med. 2014:370:1889-98.

6. Sulkowski MS, Gardiner DF, Rodriguez-Torres M, Reddy KR, Hassanein T, Jacobson I, et al. Daclatasvir plus sofosbuvir for previously treated or untreated chronic HCV infection. N Engl J Med. 2014;370:211-21.

7. WHO|Global health sector strategy on viral hepatitis 2016-2021. WHO. http://www.who.int/hepatitis/strategy2016-2021/ghss-hep/en/. Accessed 29 May 2019

8. Guadagnino V, Stroffolini T, Rapicetta M, Costantino A, Kondili LA, Menniti-Ippolito $F$, et al. Prevalence, risk factors, and genotype distribution of hepatitis $C$ virus infection in the general population: a community-based survey in southern Italy. Hepatology. 1997;26:1006-11.

9. Bellentani S, Pozzato G, Saccoccio G, Crovatto M, Crocè LS, Mazzoran $L$, et al. Clinical course and risk factors of hepatitis $C$ virus related liver disease in the general population: report from the Dionysos study. Gut. 1999;44:874-80.

10. Maio G, d'Argenio P, Stroffolini T, Bozza A, Sacco L, Tosti ME, et al. Hepatitis $C$ virus infection and alanine transaminase levels in the general population: a survey in a southern Italian town. J Hepatol. 2000;33:116-20.

11. Kondili LA, Andreoni M, Alberti A, Lobello S, Babudieri S, Roscini AS, et al. Estimated prevalence of undiagnosed HCV infected individuals in Italy: a mathematical model by route of transmission and fibrosis progression. Epidemics. 2021;34:100442.

12. Kondili LA, Robbins S, Blach S, Gamkrelidze I, Zignego AL, Brunetto MR, et al. Forecasting Hepatitis C liver disease burden on real-life data. Does 
the hidden iceberg matter to reach the elimination goals? Liver Int. 2018;38:2190-8

13. National Hepatitis Plan. Piano nazionale per la prevenzione delle epatiti virali da virus B e C (PNEV). http://www.salute.gov.it/ imgs/C_17_pubblicazioni_2437_allegato.pdf. Accessed 11 Aug 2020

14. Statistiche Istat. http://dati.istat.it/Index.aspx. Accessed 31 May 2019.

15. SEIVA: Sistema Epidemiologico Integrato dell'Epatite Virale Acuta. http:// old.iss.it/seieva/.

16. Aggiornamento dati Registri AIFA DAAs-Epatite C cronica. :4.

17. Linthicum MT, Gonzalez YS, Mulligan K, Moreno GA, Dreyfus D, Juday T, et al. Value of expanding HCV screening and treatment policies in the United States. Am J Manag Care. 2016;22(6 Spec No.):SP227-35.

18. Kondili LA, Romano F, Rolli FR, Ruggeri M, Rosato S, Brunetto MR, et al. Modeling cost-effectiveness and health gains of a "universal" versus "prioritized" hepatitis C virus treatment policy in a real-life cohort. Hepatology. 2017:66:1814-25.

19. Dienstag JL, Ghany MG, Morgan TR, Di Bisceglie AM, Bonkovsky HL, Kim $\mathrm{H}-\mathrm{Y}$, et al. A prospective study of the rate of progression in compensated, histologically advanced chronic hepatitis C. Hepatology. 2011:54:396-405.

20. Wright M, Grieve R, Roberts J, Main J, Thomas HC, UK Mild Hepatitis C Trial Investigators. Health benefits of antiviral therapy for mild chronic hepatitis C: randomised controlled trial and economic evaluation. Health Technol Assess. 2006;10:1-113 iii.

21. Townsend R, McEwan P, Kim R, Yuan Y. Structural frameworks and key model parameters in cost-effectiveness analyses for current and future treatments of chronic hepatitis C. Value Health. 2011;14:1068-77.

22. Relazione Annuale Al Parlamento Sullo Stato Delle Tossicodipendenze in Italia 2002. 2002. http://www.edscuola.it/archivio/handicap/tossicodip endenze02.pdf.

23. Andriulli A, Stroffolini T, Mariano A, Valvano MR, Grattagliano I, Ippolito $\mathrm{AM}$, et al. Declining prevalence and increasing awareness of HCV infection in Italy: a population-based survey in five metropolitan areas. Eur J Intern Med. 2018;53:79-84.

24. Hofstraat SHI, Falla AM, Duffell EF, Hahné SJM, Amato-Gauci AJ, Veldhuijzen IK, et al. Current prevalence of chronic hepatitis $B$ and $C$ virus infection in the general population, blood donors and pregnant women in the EU/EEA: a systematic review. Epidemiol Infect. 2017:145:2873-85.

25. The Italian Liver Patients' Association (EpaC). https://www.epac.it/. Accessed 20 Jul 2019

26. Li Bassi L. Le nuove modalità di approccio alla patologia e misure in itinere. 2019. https://www.epac.it/cm-files/2019/10/22/programma-preli minare-convegno-hcv-5-novembre.pdf.

27. A.I.S.F, Associazione Italiana per lo studio del Fegato. Epidemiologia delle Epatopatie Acute e Croniche in Italia. https://www.webaisforg/wp-conte nt/uploads/2019/01/epidemiologia_.pdf.

28. Shiffman ML. The next wave of hepatitis $C$ virus: the epidemic of intravenous drug use. Liver Int. 2018;38:34-9.

29. Hickman M, Martin NK, European Monitoring Centre for Drugs and Drug Addiction. Hepatitis $C$ among drug users in Europe: epidemiology, treatment and prevention. Luxembourg: Publications Office; 2016. http:// bookshop.europa.eu/uri?target=EUB:NOTICE:TDXD16002:EN:HTML. Accessed 20 Aug 2020.

30. Italy In Figures: 2015. https://www.istat.it/en/files/2015/09/ItalyinFigures2 015.pdf.

31. Kondili LA, Gamkrelidze I, Blach S, Marcellusi A, Galli M, Petta S, et al. Optimization of hepatitis $C$ virus screening strategies by birth cohort in Italy. Liver Int. 2020;40:1545-55.

32. Galli M. Epatite C: 71 milioni di euro stanziati in Italia per screening gratuiti. Osservatorio Malattie Rare. https://www.osservatoriomalattierare.it/ epatite-c/15694-epatite-c-71-milioni-di-euro-stanziati-in-italia-per-scree ning-gratuiti. Accessed 23 Sep 2020.

33. Monitoraggio settimanale Covid-19, report dal 13 al 19 luglio. http:// www.salute.gov.it/portale/news/documenti/Epi_aggiornamenti/allegati/ Punti_chiave_e_tabella_incidenza_13_19_luglio_2020.pdf.

34. Kondili LA, Marcellusi A, Ryder S, Craxì A. Will the COVID-19 pandemic affect HCV disease burden? Dig Liver Dis. 2020. https://doi.org/10.1016/j. dld.2020.05.040

35. Blach S, Kondili LA, Aghemo A, Cai Z, Dugan E, Estes C, et al. Impact of COVID-19 on global hepatitis C elimination efforts. J Hepatol. 2020. https://doi.org/10.1016/j.jhep.2020.07.042.
36. Buoro S, Di Marco F, Rizzi M, Fabretti F, Lorini FL, Cesa S, et al. Papa Giovanni XXIII Bergamo Hospital at the time of the COVID-19 outbreak: letter from the warfront.... Int J Lab Hematol. 2020:42:8-10.

37. Adinolfi LE, Rinaldi L, Nevola R. Chronic hepatitis C, atherosclerosis and cardiovascular disease: what impact of direct-acting antiviral treatments? World J Gastroenterol. 2018;24:4617-21.

38. Massimo G, Annalisa R, van den Bogaart L, Cristina N, Andrea G. HCV and immigration in Italy. Acta Biomed. 2018;89(Suppl 10):19-32.

39. Coppola N, Alessio L, Onorato L, Sagnelli C, Macera M, Sagnelli E, et al. Epidemiology and management of hepatitis $C$ virus infections in immigrant populations. Infect Dis Poverty. 2019;8.https://doi.org/10.1186/ s40249-019-0528-6.

40. Fedeli U, Avossa F, Ferroni E, De Paoli A, Donato F, Corti MC. Prevalence of chronic liver disease among young/middle-aged adults in Northern Italy: role of hepatitis B and hepatitis C virus infection by age, sex, ethnicity. Heliyon. 2019;5:e02114. https://doi.org/10.1016/j.heliyon.2019.e02114.

41. Falla AM, Ahmad AA, Duffell E, Noori T, Veldhuijzen IK. Estimating the scale of chronic hepatitis C virus infection in the EU/EEA: a focus on migrants from anti-HCV endemic countries. BMC Infect Dis. 2018;18:42.

42. Vescio MF, Longo B, Babudieri S, Starnini G, Carbonara S, Rezza G, et al. Correlates of hepatitis $C$ virus seropositivity in prison inmates: a metaanalysis. J Epidemiol Community Health. 2008;62:305-13.

43. Zampino R, Coppola N, Sagnelli C, Di Caprio G, Sagnelli E. Hepatitis C virus infection and prisoners: Epidemiology, outcome and treatment. World J Hepatol. 2015;7:2323-30.

44. Fiore V, De Matteis G, Ranieri R, Saderi L, Pontali E, Muredda A, et al. HCV testing and treatment initiation in an Italian prison setting: a step-by-step model to micro-eliminate hepatitis C. Int J Drug Policy. 2021;90:103055.

\section{Publisher's Note}

Springer Nature remains neutral with regard to jurisdictional claims in published maps and institutional affiliations.

Ready to submit your research? Choose BMC and benefit from

- fast, convenient online submission

- thorough peer review by experienced researchers in your field

- rapid publication on acceptance

- support for research data, including large and complex data types

- gold Open Access which fosters wider collaboration and increased citations

- maximum visibility for your research: over $100 \mathrm{M}$ website views per year

At BMC, research is always in progress.

Learn more biomedcentral.com/submissions 